Dept. of Biochemistry and Mycology,

Animal Health Research Institute, El-Mansoura Laboratory.

\title{
SOME STUDIES ON MYCOTIC ABORTION OF SHEEP FED ON CONTAMINATED FOOD
}

(With 4 Tables)

By

\section{R.A. EL-RAMADY; DOAA A.H. EL-MATARY; K.A. DEEB and S.A. TA WFIK}

(Received at 7/4/2009)

بعض الدراسات علي الإجهاض الفطري في الأغنام المغذاة على علائق ملوثة

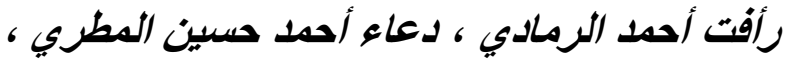

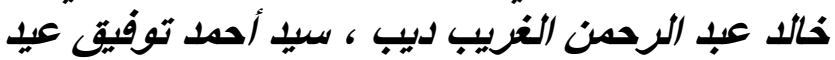

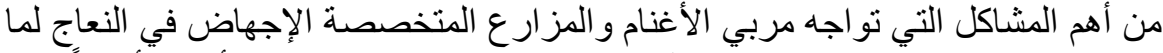

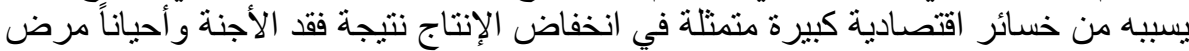

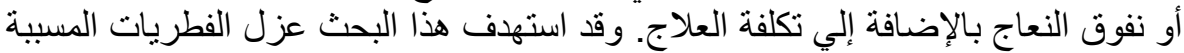

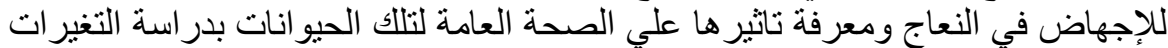

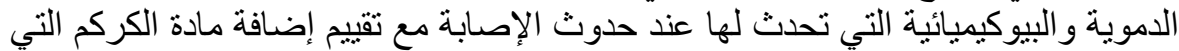

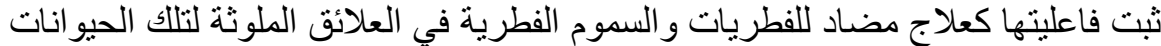

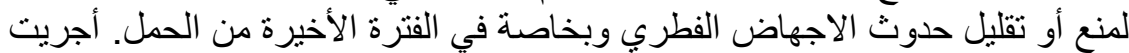

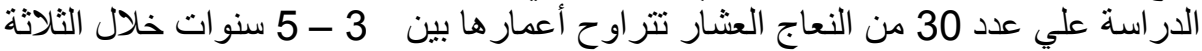

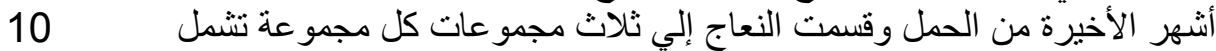

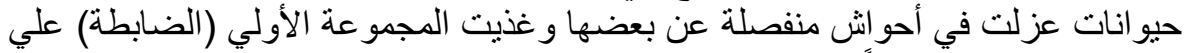

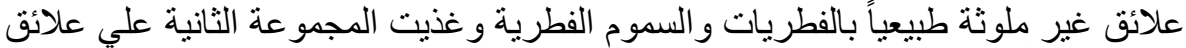

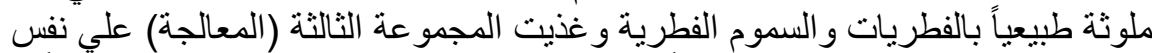

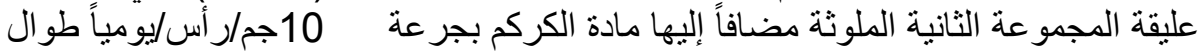

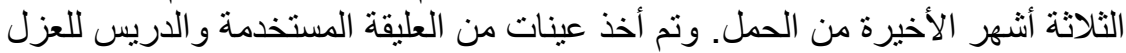

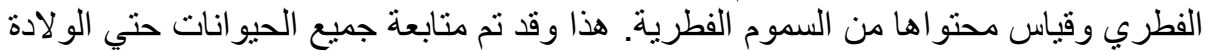

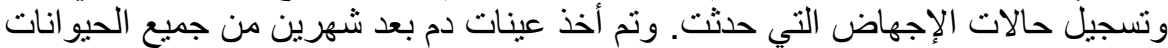

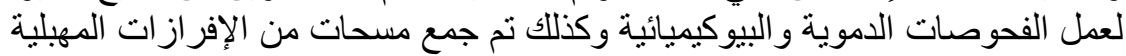

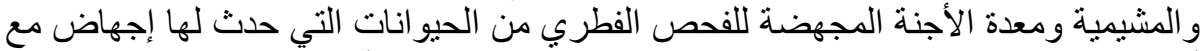

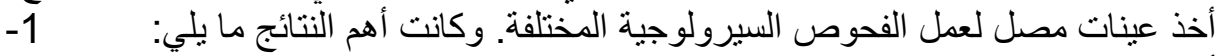

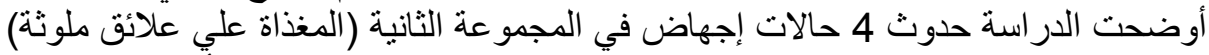

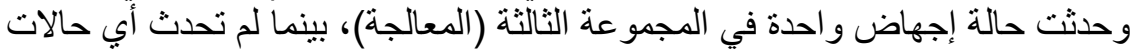

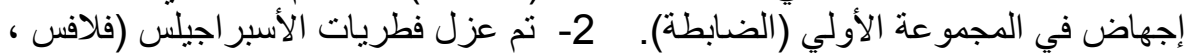

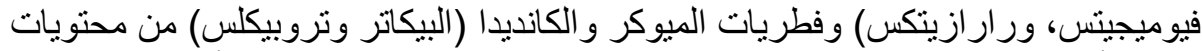

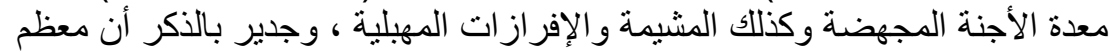


الفطريات المعزولة من الحيو انات المريضة تم عزلها من العلائق المركزة و الدريس المستخدم

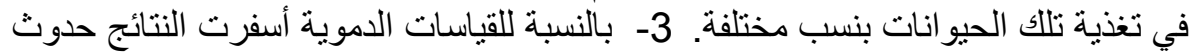

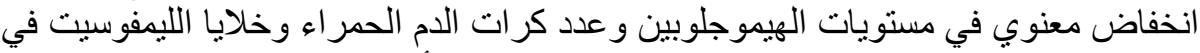

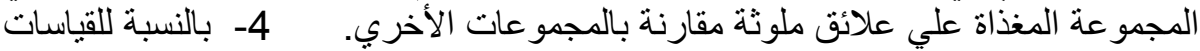

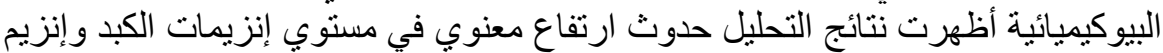

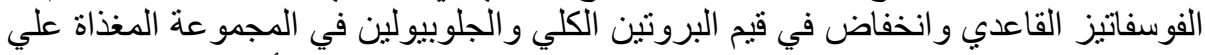

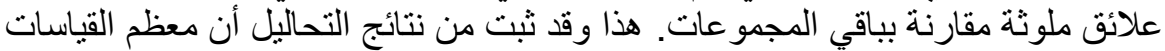

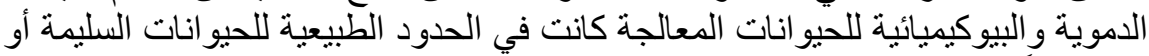

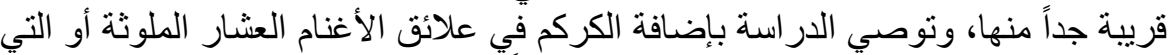

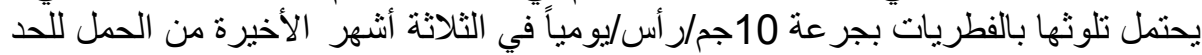
من الإجهاض الفطري في الأغنام أو تقليل نسبة الإصنابة إنهابة

\section{SUMMARY}

The aim of the present study is identification of fungi as a causative agent of abortion in sheep experimentaly fed on contaminated ration in correlates this finding with haematological and biochemical alteration before and after turmeric supplementation in ewes rations during pregnancy to evaluate these spice material in the prevention or reducing the risk of mycotic abortion especially in late of gestation period. Thirty pregnant ewes aged $3-5$ years during the last three months of pregnancy were divided randomly into three equal groups (each of 10 animals). Animals in groups $\left(\mathrm{G}_{1}, \mathrm{G}_{2}\right.$ and $\left.\mathrm{G}_{3}\right)$ were housed separately in semi-roofed yards and received uncontaminated diet (control $\mathrm{G}_{1}$ ), diet naturally contaminated with fungus and mycotoxins $\left(\mathrm{G}_{2}\right)$ and the same contaminated diet with curcumin spices at level of $10 \mathrm{gm} / \mathrm{head} / \mathrm{day}\left(\mathrm{G}_{3}\right)$. Blood and serum samples were collected from each animal at two months post feeding trial for haematological and biochemical studies. Swabs from vaginal discharge, placenta and stomach content of the aborted foeti in addition to serum samples from aborted ewes were collected for mycological and serological examination. The obtained results showed that abortion happened at the last $2-3$ weeks of pregnancy in 4 ewes $\left(G_{2}\right)$ and only in one ewe $\left(G_{3}\right)$ and was not observed in control $\left(\mathrm{G}_{1}\right)$. Mycotic examination revealed that A. flavus, A. fumigatus, A. parasiticus, Mucor species, Candida albicans and Candida tropicalis were isolated with different percentages from the collected samples. Most of isolated fungi were also recovered from concentrate and hay offered as ration for feeding. The results of blood parameters should that the mean values of $\mathrm{Hb} \%$, $\mathrm{RBCs}$ count, $\mathrm{MCH}$, $\mathrm{MCHC}$ and lymphocytes were reduced with contaminated diet $\mathrm{G}_{2}$ when compared with control $G_{1}$ or curcumin treated group $G_{3}$. The 
biochemical analysis of serum revealed significant elevation in the activities of serum enzymes AST and ALP. While the levels of serum total protein and globulin were significantly reduced in contaminated diet fed group $\left(\mathrm{G}_{2}\right)$ when compared with other groups. It could be concluded that the pollution of ration with fungi and mycotoxins may be considered important cause of abortion in pregnant ewes. The dietary supplementation of curcumin for pregnant ewes fed on polluted ration with fungi and mycotoxins at dose level (10 gm/head/day) during the last 3 months of pregnancy help in reducing the risk of mycotic abortion and improve the general health condition without any toxic effects as evidenced by haematobiochemical parameters.

Key words: Abortion, Sheep, Aspergillus, Candida

\section{INTRODUCTION}

Abortion in sheep and goat as in large animals is due to a wide variety of causes such as chemical, mechanical, nutritional, bacterial, viral and mycotic causes.

Aspergillus species is the main cause of mycotic abortion followed by Mucor, Absidia and Candida in cattle (Hoedemake and Held, 1985; Munoz and Gonazalez, 1987); and in ewes) Subhash et al., 1999 and Mohamed, 2002). Abortion usually occurred during the last trimester of pregnancy (Corbel, 1988). Aspergillus fumigatus is a fairly common in both hay and silage (Radostits et al., 2000). Mycotoxins in genital tract are spermicidal to spermatozoa (Saxena and Ishaque, 1977).

Regarding the blood chemistry and abortion in goats, Zaghloul et al. (1985) investigated the blood biochemical alteration of goats with chlamydial abortion and found an increase in the level of serum protein blood urea, nitrogen, creatinine and alanine aminotransferase.

Natural fungal poisons in mould grains strongly influence variation infertility and mortality rates, mycotoxins which influence fertility might reduce consumption and increase abortion as well as possible damaging in immune system (Matossian, 1996), it also retard growth and cause histopathological and biochemical changes in liver and kidneys. Various antifungal drugs have been used for treatment of aspergillosis (Helt and Riviere, 1995). Itraconazole reduced in $60-70 \%$ success rates and have been widely used in human medicine and recently are used in veterinary medicine (Kelly et al., 1995). 
One of the most important medicines which are used in prevention and treatment of various and serious diseases are medicinal herbs as turmeric which is the powdered dry rhizome of curcuma longa linn. plant of the family zingiberaceae. Curcumin (diferuloylmethane) is the major yellow pigment of turmeric, they are commonly used as spice food preservatives, yellow coloring and flavouring agents.

Extensive work has been done to establish the biological activities and pharmacological actions of turmeric and its extracts. Curcumin (diffruloylemethane) the main yellow bioactive component of turmeric has been shown to have a wide spectrum of biological actions, these include its anti-inflammatory, antioxidant, anticarcinogenic, antimutagenic, anticoagulant, antidiabetic, antibacterial, antifungal, antiviral, antiprotozoal, hypotensive, hypocholesteremic activities, curcumin has already been used to reduce post-operative inflammation. Also it has an potent immuno stimulant effects, so has been shown to have antiviral activity (Ishita et al., 2004).

Curcumin inhibits lipid peroxidation in different tissues of rat and mice (Okuda et al., 1993), it reduced D-galactosamine- induced glutamate oxalacetate and glutamate pyruvate transaminase level (Hikino, 1985). An either extract of C. longa have hypolipemic action in rats (Rao et al., 1970) and lower cholesterol, fatty acids and triglycerides in alcoholic induced toxicity (Rukkumani et al., 2003). Curcumin had no any adverse effect on both growth and levels of erythrocytes, leucocytes and other blood constituent as haemoglobin, total serum proteins, alkaline phosphates etc.. (Sambaiah et al., 1982).

Turmeric and curcumin have antifungal activity. Turmeric oil is also active against Aspergillus flavus, A. parasiticus, Fusarium moniliforme and Penicillium, digitatum (Jayaprakasha et al., 2001). Thus both turmeric and curcumin have the potential for the development of various diseases (Ishita et al., 2004).

Accordingly the present investigation was undertaken to study the identification of fungi as a causative agents of abortion in sheep experimentaly fed on contaminated retion and correlate these finding with haematological and serum biochemical alteration before and after turmeric supplementation in ewes rations during pregnancy to evaluate these spice material in prevention or reducing the risk of mycotic abortion especially in late of gestation period.

\section{MATERIALS and METHODS}




\section{I- Animals:}

The present investigation was carried out on 30 pregnant ewes aged 3-5 years during the last three months of pregnancy. These animals belonged to a special private farm located at Dakahlia Governorate. All animals were apparently healthy and free from any internal and external parasites after parasitological examination according to the methods described by Soulsby (1982).

\section{II- Experimental design:}

The chosen animals were allocated randomly into equal groups (each of 10 animals) each group were housed separately in semi-roofed yard.

The sheep groups were fed on experimental diet as following:

A- Uncontaminated diet fed to control group $\left(\mathrm{G}_{1}\right)$.

B- Diet contaminated with mycotoxin and fungus fed to the $2^{\text {nd }}$ group $\left(\mathrm{G}_{2}\right)$.

C- Diet contaminated with mycotoxin and fungus treated with curcumin spices fed the third group at level of $10 \mathrm{gm} /$ day according to Aggarwal et al., (2003).

Feed allowances were calculated according to NRC (1985) and the amount of concentrate feed mixture (CFM) and Trifolium Alexandrium hay were estimated to cover 40 and $60 \%$ of dry matter requirement respectively. The concentrate feed mixture (CFM) consists of $20 \%$, uncorticated cotton seed meal, $40 \%$, yellow corn $7 \%$, soyabean meal, $25 \%$, wheat brains, $5 \%$ molasses, $1.5 \%$ limestone, $1 \%$ common salts and $0.5 \%$ mineral mixture.

The feeds in experimental diet $\left(\mathrm{G}_{2}\right.$ and $\left.\mathrm{G}_{3}\right)$ were naturally contaminated during the storage period with toxins. The concentrated feed mixture was contaminated with $35.1 \mathrm{ppb}$ mixture of aflatoxins and Trifolium Alexandrium hay contaminated with $37.2 \mathrm{ppb}$ mixture of aflatoxins but the feed used in control diet $\left(\mathrm{G}_{1}\right)$ were uncontaminated with aflatoxins. Samples of feeds were analysed according to A.O.A.C. (2005).

\section{III- Samples:}

A- Swabs from vaginal discharge and parts of placenta of aborted ewes and samples from stomach contents of aborted foeti were collected under complete aseptic condition and stored at $4^{\circ} \mathrm{C}$ and send to laboratries of animal health research institutes as quickly as possible for mycological, microbiological and viral examination.

B- Serum samples were taken from the diseased and control parturient ewes for the serological (brucellosis and other causative bacterial 
agent); viral (Riftvalley fever). Blood smears were also taken for blood parasites examination.

C- Blood sampling: Two blood samples were collected from different two groups of animals under investigation after two months post treatment:

1- The first blood samples were collected in heparinized tube for the determination of total erythrocytes and total leucocytic counts, packed cells volume (PCV), haemoglobin concentration following the technique described by Coles (1986). Blood indices were also calculated.

2- The second blood samples were collected without anticoagulant for serum separation and stored at $-20^{\circ} \mathrm{C}$. Serum samples were used for determination of transaminases enzymes AST, ALT, alkaline phosphatase AP, total protein, albumine, total bilirubin, urea-N, creatinine. Glucose, total lipids, cholesterol triglyceride were determined by using commercial kits supplied by (Boehringer, Mannheim, Germany) for all colorimetric biochemical analysis, while serum globulin was calculated mathematically by substracting the albumin value from the total protein value.

D- Feed samples: A total of 10 samples were collected from concentrate (6) and hay (4). The examined samples were sent to the laboratory for mycological examination and they were analyzed chemically to determine the possible mycotoxins.

\section{IV- Mycological examination of animal samples:}

The collected samples were treated with $15 \% \mathrm{KOH}$ and examined microscopically for presence of hyphae then cultivated onto sabouraud's dextrose agar with chloramphenicol then incubated at $25^{\circ} \mathrm{C}$ and $37^{\circ} \mathrm{C}$ for (2-7 days) and the isolated fungi were identified according to Refai (1979); Christensen (1981), Kozakiewicz (1989) and Moubasher (1993).

\section{V- Mycological examination of feed samples:}

Ten grams of each samples were weighed, diluted with $90 \mathrm{ml}$ of solution prepared by adding one $\mathrm{ml}$ of tween 80 (Merck) to one litre sterile distilled water (0.001 tween 80$)$ and allowed to stand for 15-30 min with intermittent shaking before being plated. Appropriate serial 10 dilution were made, $0.1 \mathrm{ml}$ were surface plated for isolation of fungi, Sabouraud's dextrose agar (Difco) were used. Isolation and identification of the different fungi were done as mentioned before.

\section{VI- Examination of certain mycotoxins from feed samples:}


The production of aflatoxins, ochratoxin and zearalenone from the toxigenic strains of Aspergillus and Fusarium species were determined as it was described by Wander et al. (1965) and Edds (1973).

\section{Statistical analysis:}

The obtained data was statistically analyzed according to Senedecor and Cochran (1982) using SAS computer program.

\section{RESULTS}

Table 1: Number and percentage of fungal isolates recovered from the aborted ewes and from stomach contents of aborted foeti

\begin{tabular}{|c|c|c|c|c|c|c|}
\hline \multirow{2}{*}{ Fungal spp. } & \multicolumn{2}{|c|}{$\begin{array}{c}\text { Stomach contents } \\
\text { of foeti (30) }\end{array}$} & \multicolumn{2}{c|}{ Placenta (30) } & \multicolumn{2}{c|}{$\begin{array}{c}\text { Vaginal discharge } \\
(30)\end{array}$} \\
\cline { 2 - 7 } & No. & $\%$ & No. & $\%$ & No. & $\%$ \\
\hline A. fumigatus & 8 & 26.7 & 12 & 40 & 10 & 33.3 \\
\hline A. flavus & 9 & 30 & 12 & 40 & 5 & 16.7 \\
\hline C. parasiticus & 4 & 13.3 & 3 & 10 & 4 & 13.3 \\
\hline C. albicans & 3 & 10 & 2 & 6.7 & 2 & 6.7 \\
\hline C. tropicalis & 1 & 3.4 & - & 0 & - & $0-$ \\
\hline Mucor & 3 & 10 & 6 & 20 & 4 & 13.3 \\
\hline
\end{tabular}

Table 2: Levels of mycotoxins $(\mathrm{PPb})$ produced in feed samples

\begin{tabular}{|c|c|c|c|}
\hline Feed samples & Aflatoxin & Ochratoxin & Zearlenone \\
\hline Concentrates & 21 & 10 & - \\
\hline Concentrates & 12 & 9 & 10 \\
\hline Concentrates & 24 & 3 & - \\
\hline Hay & 12 & 6 & 8 \\
\hline Hay & 30 & - & \\
\hline
\end{tabular}

Table 3: Haematological parameters (mean \pm SE) of healthy pregnant ewes as affected by different experimental diets. 
Table 4: Biochemical parameters (mean \pm SE) of healthy pregnant ewes as affected by different experimental diets.

\section{DISCUSSION}

$-8-$ 
Careful clinical examination of pregnant ewes throughout this study revealed that abortion took place at the last 2-3 weeks of pregnancy in 4 ewes from group 2 (Non treated) and only in one case from group 3 (treated one) and was not observed in $\mathrm{G}_{1}$ (control group). The aborted ewes showed a rise of body temperature, rapid respiration, off food and putrified vaginal discharge. The gross post mortem of aborted foeti showed the presence of characteristic skin lesion (mycotic dermatitis) on head and neck, blood tinged with fluid in both thoracic and abdominal cavities. The post mortem lesion were similar to those previously recorded by Zaghloul and Shehata, (1991); Johnson et al., (1994) and El-Nagar et al. (1997).

Mycotic examination of stomach contents of aborted foeti and placenta and vaginal discharge of affected ewes revealed that $A$. flavus, A. fumigatus, A. parasiticus and Mucor species were isolated with a higher percentage, these results agreed with Hoedemake and Held (1985); Sheridan et al. (1985); Biberstin (1986); Macausland et al. (1987); Johnson et al. (1994); Subhash et al. (1999) and Mohamed (2002).

Candida albicans and Candida tropicalis were isolated from stomach content of foeti and from vaginal swab and placenta of aborted ewes (Table 1), this finding was in accordance with that reported by Sinha et al. (1980) and Sanford and Josephson (1988).

Results in Table 2 showed that aflatoxin was produced from feed samples more than permissible limits (15 ppb) while ochratoxin and zearlenone were in the permissible limits as recorded by FAC-Doex, (1996 \& 1999) it is interesting to mention that, most of isolated fungi from the most affected dams and aborted foeti were also recovered from concentrates, hay and barssem offered as a ration for feeding, these mycotoxins may have direct effect on the liver (Mohamed, 2002).

Concerning the haematological parameters, the results in Table 3 showed that the mean values of haemoglobin $(\mathrm{Hb} \%)$; red blood cells (RBCs); $\mathrm{MCH}$; $\mathrm{MCHC}$ and lymphocytes cells were reduced with contaminated diet $\left(\mathrm{G}_{2}\right)$ when compared with uncontaminated $\left(\mathrm{G}_{1}\right)$ but the differences were non significant in $\mathrm{Hb}, \mathrm{MCHC}$ and lymphocytes. Similar results were recorded by Allam et al. (2002) who recorded reduction in most of haematological parameters as a result to aflatoxicosis and most of other mycotoxins. On the other hand turmeric (curcumin) supplementation to contaminated diet in $\mathrm{G}_{3}$ had significantly increases in $\mathrm{Hb} \%, \mathrm{MCHC}$ and lymphocytes cells and also the same trend was observed in RBCs and $\mathrm{MCH}$ without significant. Similar results were observed by Abdelhamid et al. (2002) with some medicinal 
herbs, thyme, ginger and safflower. Aflatoxin induced immunosuppression and increased in WBCs (Harvery et al., 1995) but adding medicinal herbs overcome this serve side effects and also significant increase in immune response related to herbs addition was reported by Soliman et al. (1999) and Dawoud et al. (2000). Concerning biochemical parameter Table 4 demonstrated a significant decrease in serum total protein and globulin with decrease in albumin level with $\mathrm{G}_{2}$ (contaminated diet) compared with control group (uncontaminated diet).

These results are in accordance with those of Allam et al. (2002). But turmeric supplementation to the contaminated diet have been attempted with high degree of success to reduce toxicity and impairment of immune response during aflatoxicosis and ochratoxicosis in livestock, so the turmeric powder maintained both of total protein and globulin concentration and also the albumin value to the normal range. Thus the highest value of albumin/globulin $(A / G)$ was recorded with $G_{3}$ (0.71) and the lowest value was detected in $\mathrm{G}_{3}(0.67)$. These results are in accordance with those of Abdelhamid et al. (2002) due to single or compound mycotoxicosis in broiler. Huff et al. (1992) who reported reduction in serum total protein due synergistic action of dietary aflatoxin and ochratoxin in chicks. Reduction in serum total protein and serum albumin induced by mycotoxicosis could be due to pathological changes in liver. Kurkure et al. (2002) reported that treatment of chicks with curcumin and curcum longa $(0.5 \mathrm{~g} / \mathrm{kg}$ feed $)$ during aflatoxicosis help to maintain normal serum protein levels.

Data obtained from the present study showed that, the activities of ALT, ALP and blood urea levels were increased significantly while AST, serum total bilirubin and creatnine showed a non significant increase in $\mathrm{G}_{2}$ (contaminated diet) in comparison with control one, this finding indicated that aflatoxin ochratoxin combination had hepatotoxic and effects on ewes.

The observed results are in agreement with Mohamed (2002) who mentioned that biochemical analysis of the serum of the affected dams with mycotic abortion revealed a significant increase in the levels of albumin compared with those the apparently healthy ones. In the present study there was a significant increase in total lipids value and non significant reduction in serum chlolestrol, triglyceride level and glucose value due to dietary aflatoxin ochratoxin and feeding of these mycotoxins in combination to $\mathrm{G}_{2}$ (contaminated diet). Increase of serum cholesterol during aflatoxicosis, a similar tend was reported earlier by Mani et al. (1993) and Stoev et al. (2000) during ochratoxicosis due to combined mycotoxicosis, similar results were recorded by Huff et al. 
(1992). Reduction in serum glucose, total cholesterol and triglyceride levels on the other side total lipid elevation during induced mycotoxicosis reflects impaired liver metabolism leading to reduced synthesis of cholesterol and triglyceride and may be due to loss of appetite or depraved metabolic processes which consequently reflected upon glucose metabolism and its levels. The significant improvement of these parameters of mycotoxicated ewes $\left(\mathrm{G}_{3}\right)$ supplemented with turmeric powder in indicative of range its protective role and maintained their values to the normal ranges with the finding reported by Abdelhamid et al. (2002) who reported that blood protein and iron concentrations improved while the concentration of total lipids and the activity of ALP and ALT were reduced as a result of adding some medicinal herbs to the contaminated diet. Curcumin reduces low density lipoprotein significantly in plasma and total cholesterol level in liver along with an increase of $\alpha$-tocopherol level in rat plasma, suggesting in vivo interaction between curcumin and $\alpha$-tocopherol that may increase the bioavailability of vitamin $\mathrm{E}$ and decrease cholesterol level (Kamal Eldin et al., 2000). Turmeric supplementation to $\mathrm{G}_{3}$ (treated group) was seen to resist the change induced by mycotoxins on the studied biochemical parameters and was also made to as certain. The protective role of herbal preparation curcumin longa during induced mycotoxicosis, similar results was reported by Ashry (2003) who indicated that turmeric powder and its products produced their reductive effects on lipid peroxidation in the different tissues of rats as protective agent against cancer. Serum urea, creatinine, AST and ALT activities were discussed and revealed that turmeric powder either 10 or $20 \%$ had no any significant side effect on these parameters. Similar observation were reported by Deshpande et al. (1998) and Park et al. (2000) who recorded that the cureumin and turmeric returned the elevated levels of AST and ALT activities to normal levels in rats treated with either formadhyde or $\mathrm{Ccl}_{4}$.

It can be concluded that the dietary supplementation of turmeric powder $10 \mathrm{~g} / \mathrm{head} /$ day for the last three months in pregnant ewes feeding on the contaminated diet with mycotoxins and polluted with fungi proved to be effective as fungicidal agent and also in detoxification of the mycotoxins and improving the general health condition as seen by haematobiochemical parameters and had no toxic effects as evidenced by their effects on liver and kidney functions.

\section{REFERENCES}


A.O.A.C. (2005): Official Methods of Analysis. $16^{\text {th }}$ Ed., Association of Official analytical Chemists, Washington, D.C. USA.

Abdelhamid, A.M.; Sallam, A.E.; AbdAllah, G.A. and El-Samra, S.H. (2002): Effect of feeding male rats on aflatoxic diets without or with medicinal herbs (thyme, safflower, ginger, black cumin and/or garlic). Proc. $2^{\text {nd }}$ Conf. Food-borne Contamination and Egyptian's Health. April, El-Mansoura, Egypt.

Aggarwal, B.B.; Kumar A. and Bharti, A.C. (2003): Anticancer potential of curcumin. Preclinical and clinical studies. Anticancer Res., 23: 363-398.

Allam, S.M.; Soliman, A.A.; Ahmed, M.E. and Shebl, M.A. (2002): Aflatoxicosis in Egyptian sheep. 2- clinical chemistry and chemistry and quality. Proc. $2^{\text {nd }}$ Conf., Foodborne Contamination and Egyptians' Health, 23 - 24 April, 2002, El-Mansoura, Egypt.

Ashry, K.M. (2003): Biochemical studies on turmeric powder with special reference to antioxidant effect and possible roles in protection against chemical carcinogenesis. Assiut Vet. Med. J. 49: 99.

Biberstin, E.L. (1986): Systemic mycosis in current veterinary therapy. P. $611-619.1^{\text {st }}$ Ed. Edited by B.L. Howard Saunders Comp. Philadelphia..

Christensen, $M$. (1981): A synoptic key and evaluation of species in the Aspergillus flavus group. Mycoses. 73: $1056-1084$.

Coles, E.H. (1986): Veterinary Clinical. $4^{\text {th }}$ Ed., W.B. Saunders Comp.

Corbel, M.J. (1988): Production of antibodies to placental antigens by pregnant ewes experimentally infected with Aspergillus fumigatus. Br. Vet. J., 128, X1iv = X1vi.

Dawoud, A.S.; Salem, F.S.; Edress, N.M. and Nawar, A. (2000): Clinicopathological and Immunological studies on the effect of Nigella astiva extracts in IBDV vaccinated chicken. Proc. $5^{\text {th }}$ Vet. Med. Zag. Conf., 132 - 145, Sept., Sharm El-Sheikh, pp. 75.

Deshpande, U.R.; Gdre, S.G.; Raste, A.S.; Pillai, D.; Bhide, S.V. and Longa, L. (1998): Extraction carbon tetrachloride-induced liver damage in rats. Indian J. Exp. Biol. 36 (6): 573 - 577.

Edds, G.T. (1973): Acute aflatoxicosis A. Review J. Am. Vet. Asocc. $162-304$.

El-Nagar, A.L.; Ahmed, Y.F.; Ibrahim, F.A. and Refai, M.K.M. (1997): Mycotic abortion in small ruminants induced by Aspergillus fumigatus in Egypt. Egyptian J. of Comparative Pathology and Clinical Pathology. 10 (2): 59 - 76. 
FAC "Codex Committee on Blood Additive and Contaminants" (1996): Codex alimentary Joint. FAO/WHO food standers program 31 session CX-FAC 66/15 poisoning program 31 session CX-FAC 99/15 poisoning paper on Zeazrlenone. Netherlands.

FAC-Codex "Committee on Food Additives and Contaminants" (1999): Codex alimenterius Joint FAO/WHO food standers program 31 session CX FAC 99/14. Poisoning paper on ochratoxin A. Netherlands.

Harvey, R.B.; Edrington, T.S.; Kubena, L.F.; Corrier, D.E. and Elissada, M.H. (1995): Influence of the antibiotic lincomycin and tylosin on aflatoxicosis when added to aflatoxincontaminated diets of growing swine. J. Vet. Diagn. Invest. 7 (3): 374.

Helt, M.C. and Riviere, J.M.E. (1995): Antifungal and antiviral drugs. In veterinary pharmacology and therapeutics Ed. Adams R. $7^{\text {th }}$ ed Lowa State University Press. Ames. PP. 855 - 883.

Hikino, H. (1985): Antihepatotoxic activity of crude drug. Yakugaku Zasshi, 105: 109 - 118.

Hoedemake, M. and Held, T. (1985): Mycotic abortion in German block pied cow (short clinical communication). Praktische-Tierarzt. 66 (6): $488-489$.

Huff, W.E.; Kubena, L.F.; Harvey, R.B. and Phillip, T.D. (1992): Efficacy of hydrated sodium calcium alumino silicate to reduce the individual and combined toxicity of aflatoxin and ochratoxin A. Poult., 71: $64-69$.

Ishita, C.; Kaushik, B.; Uday, B. and Ranajit, K. (2004): Turmeric and curcumin: Biological actions and medicinal applications. Current Science, 87 (1): 44 - 53.

Jayaprakasha, G.K.; Negi, P.S.; Anadharmakrishnan C. and Sakariahk, $K$. (2001): Chemical composition of turmeric oil a by products from turmeric oleoresin industry and its inhibitory activity against different fungi. Z. Nature Forch 65: $40-44$.

Johnson, C.T.; Lupsons, G.R. and Lawrence, K.E. (1994): The bovine placentome in bacterial and mycotic abortion. Veterinary Record. 134 (11): 263 - 266.

Kamal-Eldin, A.; Frank, J.; Razdan, A.; Tengblad, S.; Basu, S. and Vessby, B. (2000): Effect of dietary phenolic compounds on tocopherol, cholesterol and fatty acids in rats. Lipids, 35: $427-435$. 
Kelly, S.E.; Shaw, S.E. and Clark, W.T. (1995): Long term survival of four dogs with disseminated Aspergillus terrus infection treated with itraconazole. Aust. Vet. J. 72: 313.

Kozakiewicz, Z. (1989): Aspergillus species on stored products. Mycological papers; 16: 1 - 188, C.A.B. International Mycological Institute Ferry Lane, Kew, Surrey, UK.

Kurkure, N.V.; Pawar, S.; Kognole, S.M.; Ganorkar, A.G. and Kalory, D.R. (2002): Ameliorative effect of turmeric curcuma Longa induced aflatoxicosis in cockerels. Ind. J. Vet. Pathol., 24: $26-28$.

Mani, K.; Narhari, D.; Kumara, R. and Ramamoorthy, J.N. (1993): influence of dietary aflatoxin Bion certain haematological and biochemical characters of broiler chicken. Ind. Vet. J., 70: $801-804$.

Matossian, M. (1996): Effect of natural fungal toxins on fertility and mortality in Connetient 1660 - 1900. J. Nutritional Med., 6: $285-300$.

Macausland, I.P.; Slee, K.J. and Hirst, F.S. (1987): Mycotic abortion in cattle. Australian Veterinary Journal 64 (5): 129 - 132.

Mohamed, A. Balata (2002): Investigation of suspected cases of mycotic abortion in does and ewes under semi aird condition. $6^{\text {th }}$ Vet. Med. Zag. Conference $(7-9$ Sep., 2000) Hurghada. $153-160$.

Moubasher, A.H. (1993): Soil fungi in Qatar other Arab countries. The Scientific and Applied Researcher Center, University of Qatar, Doha, Qatar, 566 pp.

Munoz, M.C. and Gonzalez, M. (1987): Association of mycotic agents with bovine abortion. Rerista-de-sauld- Animal. 9 (4): 366.

NRC (1985): Nutrient requirement of domestic animals. Nutrient requirement of sheep. National Research Council Washington, D.C. USA.

Okuda, Y.; Yoshida, T. and Hatano, T. (1993): Antioxidant Phenolics in oriental medicine. Cited after Yagi K. (1991): editor of active oxygen lipid peroxides and antioxidant. PP. 333-346. Japan. Sci. Press. Tokyo CRC Press, Boca Raton.

Park, E.J.; Jeon, C.H.; Ko, G.; Kim, J. and Sohn, D.H. (2000): Protective effect of curcumin in rat liver injury induced by carbon tetrachloride. J. Pharm. Pharmacol., 52 (4): 437 - 440.

Patnaik, N.; Mohanty, B.N.; Ray, S.K.H.; Mohanty, D.N. and Mishra, P.R. (1992): Clinical report on lugol's iodine treatment of mycotic abortion on bovine. Indian Vet. J. 69: 1029 - 1031. 
Radostits, O.M.; Gay, C.C.; Blood, D.C. and Hinchcliff, K.W. (2000): Veterinary Medicine $9^{\text {th }}$ Ed. W. B. Saunders Company Ltd, London, New York, Philadelphia, San Francisco, St Louis, Sydney.

Rao, S.D.; Chandrashekhara, N.; Satyanarayana, M.N. and Srinivasan, M. (1970): Effect of curcumin on serum and liver cholesterol levels in the rate. J. Nutr., 100: 1307-1315.

Refai, M.K. (1979): Isolation and Identification of fungi. Published by Faculty of Vet. Med., Cairo University.

Rukkumani, R.; Sribalasubashini, M. and Menon, V.P. (2003): Protective effect of curcumin and photo-irradiated curcumin on circulatory lipids and lipid peroxidation products in alcohol and polyunsaturated fatty acid induced toxicity. Phytother Res., 17: $925-929$.

Sambaiah, K.; Ratankumar, S.; Kamanna, V.S.; Satyamarayana, M.N. and Rao, M.V.L. (1982): Influence of turmeric and curcumin on growth, blood constituent and serum enzymes in rats. J. Food Sc. Technol., 19: 187 - 190.

Sanford, S.E. and Josephson, G.K.A. (1988): Candida parapsilosis abortion in cow. Candidian Veterinary Journal. 29 (5): 458.

Saxena, S.C. and Ishaque, M. (1977): Therapeutic evaluation of antimycotic drugs in repeat breeding bovines due to mycotic infection. Current Science, 46: 780 - 782.

Sendecor, G.W. and Cochran, W.G. (1982): Statistical Methods. $7^{\text {th }}$ Ed. Iowa State Univ. Press, Ames. Iowa, USA.

Sheridan, J.J.; White, D.S.C.; McGrvie, Q.D. (1985): The occurrence of organisms concerned with bovine abortion in Israel. Israel Journal of Medical Science. 23 (7): 864.

Soliman, A.Z.M.; Ghazalah, A.A.; El-Samra, S.H.; Atta, A.M. and Abdo, Z.M.A. (1999): The synergistic effect of either black seed or garlic with fat and broiler performance and immunity. Egypt. J. Nutr. Feeds (Special Issue), 603.

Soulsby, E.J. (1982): Helminths, arthropods and Protoza ofdomesticated animal. $7^{\text {th }}$ Baillier Tindall and Casselltd.

Stoev, S.D.; Anguleov, G., Ivano, I. and Pavlov, D. (2000): Influence of $\mathrm{OA}$ and an extract of artichoke on the vaccinal immunity and health in broiler chicks. Exp. Toxicol. Pathol., 52: 43 - 55.

Subhash Vetma; Ramesh C. Katoch; Satish K. Jand. and Parag Nigam (1999): Fungi associated with abortions and infertility in does and ewes. Veterinarski Arhiv 69 (1): 1 - 5. 
Wander, K.J.; Steyn, P.S.; Fouris, L.; Scott, De. B. and Theron, J.J. (1965): Ochratoxin A, A toxin metabolites produced by A. ochraceus. Wilth Nature 205: 1112.

Zoghloul, A.H; Abdel Aal, Th.S. and Nafie, Th.S (1985): Some biochemical alteration in blood serum of goats with chlamydial abortion In Abstracts of the Second National Conference of Biochemistry, Cairo.Pp.123 - 124.

Zoghloul, A.M. and Shehata, S.H. (1991): The clinical picture of mycotic abortion in buffalo cows. Assiut Vet. Med. J., 25 (49): $203-210$. 